\title{
UNSUR MAGI TUKANG TARI PADA SENI TARI TRADISI PACU JALUR DI KABUPATEN KUANTAN SINGINGI PROVINSI RIAU
}

\author{
Desti Kumala Sari \\ Program Pascasarjana, Universitas Negeri Semarang \\ E-mail: destikumala12@yahoo.com
}

\begin{abstract}
Abstrak
Pacu Jalur merupakan sebuah tradisi dari masyarkat Kabupaten Kuantan Singingi Provinsi Riau yang mengandung unsur seni berupa seni rupa, tari, musik dan sastra yang merupakan filosofi dari kehidupan masyarakat setempat serta di dukung oleh unsur olahraga dan magis. Percampuran tradisi ini menjadikan Pacu Jalur sebagai salah satu objek pariwisata unggulan Provinsi Riau yang berkembang sejak abad ke 17 sampai sekarang. Perkembangan ini tidak terlepas dari peranan masyarakat yang mampu menjaga dan melestarikan tradisi ini hingga sekarang. Adapun unsur kepercayaan masyarakat setempat yang sangat memegang teguh budaya nenek moyang sebagai bukti penghormatan dan perlindungan terhadap lingkungan, unsur magis sangat kental pada tradisi ini mulai dari awal sampai akhir prosesi yang tak luput dari pengaruh magis berdasarkan kepercayaan masyarakat setempat.
\end{abstract}

Kata kunci: unsur magi, Tukang Tari, Pacu Jalur

\section{MAGIC ELEMENTS OF TUKANG TARI IN PACU JALUR DANCE TRADITION IN THE DISTRICT OF KUANTAN SINGINGI, RIAU PROVINCE}

\begin{abstract}
Pacu Jalur is a tradition in Kuantan Singingi regency of Riau Province, which contains art elements in the form of art, dance, music, architerature, and the philosophy of local community and supported by elements of sports and magic as well. The mixing of this tradition makes the Pacu Jalur as one of the leading tourism objects of Riau Province that developed since the $17^{\text {th }}$ century until now. This development is not spared from the role of society that can keep and preserve this tradition until now. As for the element of belief of the local community that is strongly upholding the culture of the ancestors as a proof of respect and protection of the environment, the magic element is very thick in this tradition from the beginning to the end of the procession did not escape from the magic influence based on local beliefs.
\end{abstract}

Keywords: magic element, Tukang Tari, Pacu Jalur

\section{PENDAHULUAN}

Kebudayaan yang beraneka ragam dalam kehidupan masyarakat dapat memberikan pandangan yang berbeda-beda bagi masyarakat pendukungnya, yang mana dapat menggabarkan kehidupan dan nilai-nilai sosial masyarakat yang terkandung didalamnya. kebudayaan tak lepas kaitannya dari unsur seni yang mana seni mempunyai peranan penting dalam kehidupan sosial. kesenian berkedudukan sebagai media komunikasi antara manusia dan manusia dan alam, antara manusia dan maha pencipta (Yudasono, 1993:59).

Perkembangan seni di wilayah Provinsi Riau yang mayoritas penduduknya merupakan percampuran antara suku Melayu dan Minang 
kabau membentuk keberagaman kegiatan tradisi yang bertumpah ruah di setiap Kabupaten Kota yang ada di Provinsi Riau. Salah satunya adalah Tradisi Pacu Jalur yang berada di Kabupaten Kuantan Singingi yang secara letak geografis merupakan perbatasan sebelah barat antara Provinsi Riau dengan Sumatra Barat, tradisi Pacu Jalur merupakan objek pariwisata unggulan yang ada di Provinsi Riau yang mana keberadaan dan eksisitensinya dari tahun ke tahun mengalami peningkatan yang sangat baik.

Tradisi Pacu Jalur yang menjadi kebanggan masyarakat Provinsi Riau khususnya Kabupaten Kuantan Singingi ditambah dengan telah masuknya Tradisi Pacu Jalur ini dalam kalender pariwisata Nasional Indonesia, serta keberadaan yang dapat menarik para wisatawan mancanegara, Even Pacu Jalur yang menjadi even nasional ini sendiri dilakukan hanya 1 kali dalam setahun, Tradisi Pacu Jalur sendiri sangat kental dengan unsur kesenian, segala unsur yang ada dalam tradisi ini memiliki makna filosofis yang erat kaitannya dengan kehidupan sosial masyarakat.

Pada tradisi Pacu Jalur sendiri mengandung 4 (empat) unsur kesenian yakni Seni Rupa, Seni Tari, Seni Musik, Dan Seni Sastra. Sedangkan berdasarkan pada bentuknya kesenian sendiri dapat dibagi atas 3 (tiga) kategori, yaitu seni rupa (visual art), seni pertunjukan (performing art) dan seni arsitektur. Adapun tradisi ini tergolong kedalam seni pertunjukan. Kesenian dalam perwujudan kultural dengan sangat jelas memperlihatkan keanekaragaman tradisi di tanah air kita. Tradisi Pacu Jalur sendiri dapat di analilis dari berbagai sudut pandang mulai dari olahraga, unsur seni, unsur filosofi, mitos dan magis.

Dalam hal ini penulis akan menganalisis Unsur Magi Tukang Tari pada Seni Tari Tradisi Pacu Jalur di Kabupaten Kuantan Singingi Provinsi Riau, Ketertarikan penulisan ini di karenakan unsur seni tari disini diakitkan dengan hal Magi, yang dianalilis melaui pendekatan Magi, dengan Teori J.G. Frazer yang mengatakan bahwa magi sama sekali tidak beraitan dengan agama yang difenisikannya sebagai suatu orientasi kearah roh, dewadewa atau hal-hal yang lain yang melampaui susunan alam atau komunikasi fisik. Sehingga keparcayaan terhadap unsur magi sendiri telah menjadi sebuah ideologi atau sebuah paradigma ketika sudah berakar lama, digunakan sebagai acuan hidup dan menyentuh ranah norma sosial yang berlaku di masyarakat.

Namun karena kurangnya literatur mengenai Tradisi Pacu Jalur sendiri membuat penulis harus memulai penelitian dengan mengajukan pertanyaan kepada para informan, para informan merupakan orang yang ada hubungan langsung dengan kegiatan Pacu Jalur, serta pengamatan penulis secara langsung mengenai proses, unsur, tujuan dan fungsi yang sudah ada, pengamatan ini dapat dipertanggung jawabkan dikarenakan penulis sudah melihat dan berada dalam lingkup kebudayaan tersebut dan menjadi bagian didalamnya.

\section{MAGI}

Menurut Honig (1993:17), kata "magi" (Sihir) berasal dari kata Persia, yaitu Maga yang berarti imam. Dalam agama primitive pengertian "magi" lebih luas dari pada "sihir". Dalam pandangan mereka magi adalah suatu cara berfikir dan cara hidup, yang mempunyai arti lebih tinggi daripada apa yang diperbuat oleh seorang ahli sihir. orang yang menjalankan magi atau percaya kepada magi mendasarkan pendapatnya kepada hal-hal berikut :

a. Bahwa dunia ini penuh dengan daya-daya gaib, serupa dengan apa yang dimaksud oleh orang modern dengan daya-daya alam

b. Bahwa daya-daya alam gaib itu dapat digunakan.

Lebih lanjut, Honig (1993:17) menjelaskan bahwa secara garis besar dapat dikatan bahwa magi adalah kepercayaan dan praktik dimana manusia meyakini secara langsung mereka dapat mempengaruhi kekuatan alam dan antar mereka sendiri, entah untuk tujuan baik atau buruk, dengan usaha-usaha mereka sendiri dalam memanipulasi daya-daya yang lebih tinggi.

Sedangkan meurut Dhavamony (1995:58), magi adalah upacara dan rumusan verbal yang memproyeksikan hasrat manusia ke dunia luar 
atas dasar teori pengontrolan manusia untuk suatu tujuan. Halivaland (2000, jilid 2 :210) menjelaskan magi dalam pandangan antropologi klasik merupakan penerapan kepercayaan bahwa kekuatan supernatural dapat dipaksa untuk aktif dengan cara tertentu, baik dengan tujuan yang baik maupun yang jahat, dengan menggunakan rumusan-rumusan tertentu. Banyak masyarakat yang mengenal ritual magi untuk menjamin panen yang baik, mendapatkan binatang buruan, kesuburan, menghindarkan dan menyembuhkan penyakit manusia.

Magi adalah suatu fenomena yang sangat dikenal dan umumnya di pahami, namun tampaknya sangat sulit dirumuskan dengan tepat. Secara garis besar dapat dikatakan bahwa magi adalah kepercayaan dan praktik menurut mana manusia yakin bahwa secara langsung mereka dapat mempengaruhi kekuatan alam dan antar mereka sendiri, entah untuk tujuan baik atau buruk, dengan usaha-usaha mereka sendiri dalam memanipulasi daya-daya yang lebih tinggi.

Menurut Frazer, magi sama sekali tidak berkaitan dengan agama yang didefenisikannya sebagai suatu orientasi ke arah roh, dewa-dewa atau hal-hal lain yang melampaui susunan alam atau komunikasi soaial fisik (Dhavamony, 201049). J.G.Frazer mendefinisikan magis sebagai bentuk ketidakmampuan manusia menghadapi alam semesta, yang dilampiaskan melalui berbagai cara untuk memahami dan mengubah kondisi alam agar berjalan sesuai keinginannya (Frazer, 2009: 124). Melampaui pandangan Tylor tentang magis, Frazer mengatakan bahwa segala sesuatu yang bisa disatukan secara mental, maka harus digabungkan dengan dunia luar yang nyata (non-mental). Hubungan ini, didasarkan pada dua tipe, pertama, imitatif, menghubungkan dua magis yang prinsipnya sama, dan kedua, penularan, yaitu menghubungkan dua magis dengan alasan keterikatan.

Menurut Frazer, magis itu dibangun berdasarkan asumsi bahwa ketika satu ritual dilakukan secara tepat, maka akibat yang ditimbulkan juga akan terwujud seperti yang diharapkan. Hal ini menandakan bahwa masyarakat primitif telah memiliki pengetahuan dan menerapkan hukum-hukum tentang cara kerja alam dan berusaha mengontrolnya. Dan pada masyarakat primitif, orang yang berkuasa adalah orang yang memiliki kemampuan magis yang lebih kuat.

Dalam hal ini ahli magi tidak memohon pada kuasa yang lebih tinggi, ia tidak menuntut untuk kepentingan mahkluk yang tidak tetap dan suka melawan, ia tidak merendahkan diri dihadapan dewata yang hebat. Namun kekutan yang betapapun besarnya, sebagaimana dipercayai bersifat tidak terbatas. Frezer berpendapat bahwa ahli magi mempunyai kaitan lebih erat dengan ilmuan dari pada agamawan. ahli magi dan ilmuan, keduanya menganggap rangkaian kejadian sebagai sesuatu yang pasti dan mengikuti aturan dengan sempurna, terbatasi oleh hukum-hukum yang tidak berubah, yang operasinya dapat diramalkan dan diperhitungkan dengan tepat, unsur-unsur spontanitas, kebetulan dan musibah dikecualikan dari jalan alam.

Satu-satunya perbedaan antara ilmu dan magi adalah bahwa ahli magi menggunakan suatu konsepsi menyeluruh yang keliru tentang alam, tentang hukum-hukum khasus yang mengatur kejadian itu, karena keiripan dan persentuhan bukanlah dasar penyebab yang sesungguhnya dalam alam. Di samping itu, sikap heran dan kagum, berkenaan dengan kekuatan magis, dalam ahli magi tidak ditemukan dalam ilmuwan suatu fakta yang gagal di catat Frazer. Berbeda dari ilmuwan, ahli magi mencoba menghubungkan dan bahkan mengontrol dengan sarana upacara khusus, daya yang menampakkan diri dalam fenomena alam dan kehidupan manusia.

\section{TENTANG KESENIAN \\ a. Tradisi Pacu Jalur}

Tradisi Pacu Jalur merupakan kekayaan kebudayaan yang dimiliki oleh Indonesia yang berkembang khususnya diwilayah Riau yakni kabupaten Kuantan Singingi, yang mana tradisi ini menjadi agenda tahunan yang sudah ada dan dilestarikan serta bertahan keberadaannya dari masa ke masa hingga menjadi even nasional tahunan bahkan sekarang sudah menjadi daya Tarik bagi wisatawan mancanegara. adapun 
makna dari Kata Jalur dalam dialek melayu Rantau Kuantan sendiri pandanan makna secara tepat dalam Bahasa Indonesia sulit untuk dicari, namun penjelasan dalam berbagai kamus Bahasa Indonesia dan Kamus Dewan dapat membantu memahami kata tersebut, seperti dijelaskan oleh W.J.S. Poedarminta (1996: 227), jalur adalah barang tipis panjang; sedangkan Sulchan Yasyin (1997:231) menjelaskan jalur adalah sampan kecil yang dibuat dari sebatang pohon, perahu belongkang; dalam Kamus Dewan (2005:602) dijelaskan jalur adalah perahu yang dibuat dari sebatang kayu yang dikorek.

Penjelasan beberapa kamus diatas sedikit banyaknya dapat menjelaskan dan menggambarkan jalur seperti yang dipahami oleh masyarakat Melayu Kuantan. Dalam dialek masyarakat Kuantan Singingi, jalur adalah sebuah perahu pada awal abad ke 17 yang digunakan sebagai alat transportasi utama warga desa di Rantau Kuantan yang berbeda di sepanjang Sungai Batang Kuantan. Panjang sebuah jalur berkisar Antara 40-50 meter dengan muatan yang bisa diisi Antara 40-50 orang, dengan lebar ruang tengah kira-kira 1-1,25 meter (Wawancara, Nopris andika Putra, 3 Oktober 2015; lihat juga UU. Hamidy, 2005;8). Pacu Jalur terdiri dari dua kata, yaitu pacu dan jalur. yang mana Pacu adalah Perlombaan memacu atau mendayung. Dengan demikian, $\mathrm{Pacu}$ Jalur adalah perlombaan dayung menggunakan jalur tradisional yang menjadi ciri khas daerah Kuntan Singingi.

Seperti yang telah dijelaskan sebelumnya di awal abad ke 17 jalur merupakan alat transportasi utama warga desa di Rantau Kuantan. jalur sendiri pada masa itu benar-benar digunakan sebagai alat angkut transportasi penting bagi warga, terutama untuk alat angkut hasil bumi penduduk. Sebelum kedatangan Belanda, daerah Rantau Kuantan dikuasai oleh pemuka adat terutama para penghulu masing-masing suku. Pacu Jalur sendiri digelar pada saat perayaan hari besar agama islam setiap tahunnya, bagi pemenang Pacu Jalur biasanya diberi hadiah oleh para penghulu (pemuka adat) berupa merewa (Bendera yang berbentuk segitiga yang terbuat dari kain yang berwarna-warni dengan renda-renda pada bagian pinggirnya).
Dengan masuknya Belanda pada tahun 1905 pada wilayah Rantau Kuantan dengan menduduki Kota Teluk Kuantan. Belanda memanfaatkan tradisi Pacu Jalur ini dengan melanjutkannya sebagai perayakan hari kelahiran Ratu Wilhemina setiap tanggal 31 agustus. Karena Pacu Jalur ini diadakan hanya sekali setiap hari kelahiran Ratu Wilhemina, maka perayaan pesta ini pada setiap tahunnya dipandang oleh penduduk Rantau Kuantan sebagai datangnya tahun baru dan dilaksanakan di Teluk Kuantan, dan atas dasar itulah sebagian warga masyarakat hingga sekarang masih ada yang menyebut kegitan Pacu Jalur sebagai Tembaru (Tahun Baru).

Sedangkan pada zaman pendudukan Jepang serta agresi pertama dan kedua yang mengakibatkan bencana besar bagi seluruh sektor kehidupan masyarakat, khususnya sektor kehidupan ekonomi, telah menyebabkan jalur pada waktu itu untuk sementara harus diabaikan oleh masyarakatnya. Sampai kira-kira tahun 1950. aktivitas pacu jlaur masih belum kembali dalam kehidupan kebudayaan masyarakat Rantau Kuantan. Setelah tahu 1950, setelah kehidupan masyarakat bertambah stabil dan keadaan ekonomi berangsur-angsur membaik dengan makin naiknya harga karet alam (karet alam merupakan sumber penghasilan mayoritas warga Kuantan Singingi), maka masyarakat daerah kembali membangkitkan kegitan $\mathrm{Pacu}$ Jalur dalam kehidupan masyarakat. Hal ini dikarenakan masyarakat yang sudah merasa terikat dengan kegiatan tradisi yang memang merupakan hakikat hidup manusia, hakekat karya, hakekat budaya, dan hakekat hubungan manusia dengan alam.

Dengan bangkitnya kembali Pacu Jalur sekitar tahun 1951-1952 yang kembali diperingati dengan mengambil bagian dalam mengisi sejarah kehidupan masyarakat yakni dalam memperingati Hari Kemerdekaan Republik Indonesia setiap tanggal 17 agustus (UU. Hamidy, 2005 : 2-10). Bahkan acara pembukaan dan pelaksaanan Pacu Jalur tahun 2006 pernah dihadiri oleh Wakil Presiden RI.Yusuf Kala serta Mentri Kebudayaan dan Pariwisata RI. Jero Wacik, mengatakan pengakuannya 
bahwa "Pacu Jalur merupakan Pesta Rakyat dan Pesta Budaya yang paling ramai, paling digemari, dan paling didukung oleh seluruh lapisan masyarakat, sepanjang yang ia ketahui dan hadiri". Sekarang upacara adat khas daerah Kuantan Singingi ini diselenggarakan setiap satu tahun sekali untuk merayakan HUT Kemerdekaan Republik Indonesia, tepatnya pada tanggal 23-26 Agustus. Serta diikuti oleh ratusan perahu jalur dari berbagai provinsi riau bahkan provinsi lain, dan melibatkan beriburibu atlit dayung, serta dikunjungi ratusan ribu penonton, baik wisatawan domestik maupun mancanegara. Selain perlombaan Pacu Jalur, dalam pesta rakyat ini juga terdapat rangkaian tontonan lainnya, Yakni pertunjukan Budaya yang ditampilkan pada malam hari selama Pacu Jalur digelar sehinnga pada saat Pacu Jalur berlangsung dari pagi hingga malam maka seluruh warga akan disugukan dengan penampilan seluruh kebudayaan yang bersatu padu dalam pertunjukan yang sangat menarik yang hanya bisa disaksikan sekali dalam setahun, diantaranya Pekan Raya, Pertunjukan tarian, Pementasan Lagu daerah, Randai kuantan singingi, serta pementasan kesianan tradisional lainnya dari berbagai kabupaten di Provinsi Riau.

\section{b. Unsur Seni yang ada dalam Pegelaran Pacu Jalur di Kuantan Singingi}

Jalur merupakan hasil karya budaya yang memiliki nilai estetik tersendiri, dan juga mencangkup kreativitas dan imaginasi. Hal ini terlihat dengan jelas dari beberapa seni kreasi budaya yang terdapat pada jalur, seperti Seni Rupa berupa seni Ukir, Seni Tari, Seni Musik, dan Seni Sastra. Sehingga dapat dikatakan bahwa jalur merupakan upaya masyarakat Rantau Kuantan Masa lalu untuk memenuhi kebutuhan manusia akan rasa indah, dan sebagai penikmat keindahan. adapun unsur sei yang terkadung pada tradisi ini yakni :

a. Seni Rupa berupa seni ukir sendiri dapat dilihat pada seluruh bagian Jalur yang mana mulai dari bentuk dan ukiran dari Luan (Haluan depan) sampai ke pinggiran Badan jalur hingga Kemudi (ujung jalur). b. Seni Tari, pada PacuJalur sendirimerupakan simbol tanda yang digunakan bagi penonton dan para peserta yang sedang berpacu untuk menentukan menang atau kalahnya haluan jalur yang sedang berpacu. Seni tari disini dipertunjukan oleh satu orang penari yang disebut oleh Masyarakat Rantau Kuantan sendiri dengan sebutan Tukang Tari.

c. Seni Musik, pada tradisi Pacu Jalur sendiri seni musik menjadi bagian pendukung penyemarak pertandingan, permainan musik ini diamiankan menggunakan alat musik khas dari Kuantan Singingi yakni "Calempong", iringan musik ini bagi masyarakat Rantau Kuantan disebut dengan musik "Rarak". Saat pertandingan berlangusung maka permainan musik Rarak menjadi iringan yang akan berdengung di area pertandingan, namun sekarang musik Rarak menjadi pengering saat pembawa acara memandu pertandingan memalui saluran radio yang berkumandang di area pertandingan.

d. Seni Sastra, Dalam hal ini berhubungan dengan unsur-unsur Magis dalam tradisi Pacu Jalur khusunya diperankan oleh dukun atau pawang yang berkaitan dengan Matra-matra yang dipercaya mampu memperlancar pertandingan, baik dalam proses pertandingan maupun sebelum pertandingan.

\section{c. Seni Tari pada Tukang Tari Jalur}

Seni tari pada tradisi Pacu Jalur merupakan salah satu dari unsur kesenian yang menarik pada pertunjukannya, yang mana tukang tari disini dilakukan oleh anak yang berumur 10 tahun sampai dengan 12 tahun dengan persyaratan mampu berenang dengan baik dan mempunyai bobot tubuh yang tidak terlau berat, Tukang Tari disini adalah anak yang menari didepan Haluan Jalur yang sedang berpacu, Biasanya tukang tari tidak dilakukan melalui seleksi tapi kenginan dari anak sendiri sebab masyarakat percaya bahwa sebenarnya Tukang Tari telah dipilih oleh Roh yang ada pada jalur, sebab saat Jalur dibawa pulang ke desa konon ia sudah menentukan pilihan atas siapa yang 
bisa menaiki jalur tersebut sehingga pasti ada anak yang mau menjadi Tukang Tari dari jalur yang sudah ada.

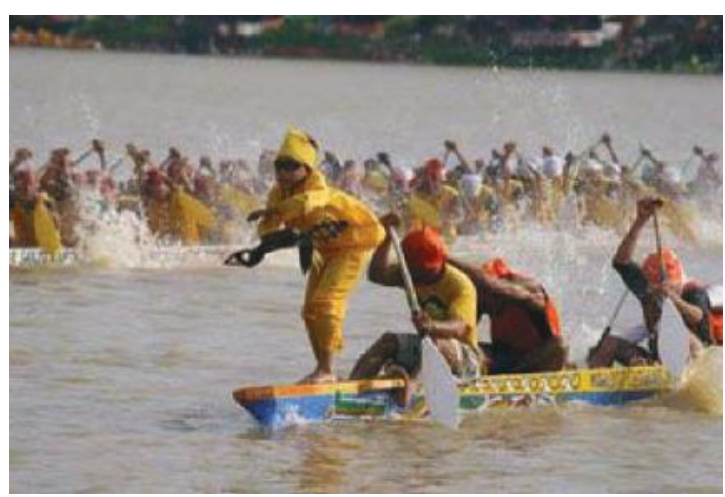

Tukang Tari Jalur

Dokumentasi Pacu Jalur Tahun 2016

(Lokasi Tepian Narosa Teluk Kuantan)

Tukang Tari di sini berada pada posisi Luan (Haluan) yang berada paling depan yang memberikan makna tersendiri yang mana, apabila si Tukang Tari salah satu Jalur berdiri itu menandakan bahwa Jalur itulah yang berada didepan haluan jalur lawan, maka Tukang Tari membutuhkan keseimbangan dan konstentasi yang tinggi untuk berdiri seimbang dan melihat ke hadapan jalur lawan, yang mana ia harus melihat haluan jalur, membuat ancang-ancang berdiri kemudian melakukan gerakan secara spontanitas yang konon katanya merupakan gambaran dari Roh Jalur Tersebut, karena banyak yang berpendapat bahwa tidak mungkin seorang anak dapat berdiri dan duduk dengan santai di atas jalur yang sedang berpacu dengan kesadaran dan spontanitas gerak yang yang beragam motif serta bentuk.

Gerak tari yang dilakukan oleh Tukang Tari jalur sendiri berbeda-beda dan tidak dapat dilihat bentuk serta motifnya. Berdasarakan wawancara secara pribadi terhadap para Tukang Tari setelah selesai berpacu ia mengatakan tidak mengingat tentang apa yang telah dilakukan di atas jalur tersebut, bentuk gerak seperti apa Tukang tari tak bisa menyontohkan kembali apa yang sudah ia lakukan (Wawancara bersama Rizul Putra: Tukang Tari Jalur Lintah Jalang pada Tanggal 22 Agustus 2015). Itulah sebabnya Pacu Jalur sendiri tak bisa di lepaskan dari Unsur magis yang mau tidak mau masih dipercai oleh seluruh masyarakat terutama dalam pelaksaanan $\mathrm{Pacu}$ Jalur yang segala unsurnya selalu diikaitkan dengan kepercayaan Magis.

Dalam prinsip-prinsip gerak sendiri terdiri atas prinsip energi dan kekuatan serta Prinsip gravitasi belans (Hawkins, 1990: 102), yang mana dalam kajian ini menurut teori sendiri Gerak Tari tak dapat dilepaskan dengan unsur keseimbangan. Sehingga dalam bentuk atau motif yang tidak baku ini dalam tari disebut juga dengan Tari Kontemporer yakni tidak terikat pada unusur gerak yang baku, akan tetapi tetap memiliki makna didalam bentuknya maupun unsur pembawaan dari penarinya.

Adapun properti yang digunakan Tukang Tari berbeda-beda ada yang menggunakan Penganyuh anak tari, yaitu yang digunakan oleh Tukang tari selain berfungsi untuk mendayung juga sebagai bentuk properti tarian yang diamiankan dan diputar saat menari, akan tetapi ukuran pendayung ini lebih kecil dari pada pendayung atlit. Adapula yang menggunakan Mayang (Bunga pinang yang belum merekah yang berwarna kehijau-hijauan maupun kekuning-kuningan) yang mana mayang ini dipegang dan juga menjadi properti bagi Tukang tari.

Berdasarkan pengalaman dan pengamatan Bentuk tari dari Tukang tari jalur sendiri tak lepas dari gerakan yang sederhana namun pertumpu pada tingkat konsentrasi dan keseimbangan yang dibuat oleh Tukang Tari yang mana gerakan membuka tangan dengan selebarlebarnya kemudian memainkan dengan pola bentuk gerak ke atas, ke samping, dan seolah menirukan bentuk gerak binatang seperti burung yang sedang terbang, diikuti dengan pola badan ke samping, membungkuk, lurus, dan turun naik, membuktikan kemampuan keseimbangan yang baik dilakukan oleh para Penari Tukang tari Jalur dengan risiko terjatuh ke dalam arus Batang Sungai Kuantan dengan Kedalaman kira-kira 6-8 meter (Wawancara Noti Arisda, S.Sn selaku Bendahara DKC Kec. Gunung Toar dalam perlombaan Pacu Jalur Tahun 2013 di Kec. Gunung Toar). Yang mana keseimbangan sendiri merupakan hal yang paling penting 
yang harus dikuasi oleh seorang penari, karena apabila tubuh tidak dapat menyeimbangkan Antara gerak maka tidak dapat mengahasilkan gerakan yang indah dan sesuai dengan bentuk gerakan yang diharapkan.

Kostum atau busana yang digunakan pada Tukang tari jalur sendiri biasanya menggunakan baju Teluk Belanga (Teluk Belango) dengan warna khas simbolis masyarakat Kuantan Singingi, yakni merah, kuning, hijau, dan hitam serta warna lainnya sesuai dengan motif jalur dan keseragaman baju para pendayung dari jalur tersebut, sedangkan diatas kepala tukang tari biasannya memakai ikat kepala menyerupai Tanjak Melayu, Namun dalam hal ini tidak menggunakan kain songket melainkan kain biasa yang di jahit menyerupai tanjak serta disesuaikan juga dengan warna bajunya, kemudian sebagian Tukang Tari jalur juga memakai kaca mata, yang mana kacamata disini selain sebagai pelengkap penampilan juga untuk melindungi mata Tukang tari dari sinar matahari dan percikan air kuantan saat jalur sedang berpacu.

\section{UNSUR MAGI TUKANG TARI PADA TRADISI PACU JALUR}

Pandangan Frazer pada hubungan magi digunakan dalam menganalisis/mengkaji Unsur Magi Pada Seni Tari Tukang Tari Tradisi Pacu Jalur di Kabupaten Kuantan Singingi Provinsi Riau. Dalam perkembangannya Tradisi $\mathrm{Pacu}$ Jalur sendiri dimulai dari proses awal telah mengaitkan unsur magis didalamnya, sebelum membuat jalur hal utama yang harus dilakukan oleh masyarakat sekitar adalah memutuskan siapa yang akan menjadi dukun jalur. menurut kepercayaan masyarakat setempat, setiap tempat atau benda senantiasa dikuasai oleh kekuatan gaib (Hasbullah 2015:157). Proses pembuatan jalur dari awal sampai akhir tak luput kaitannya dengan unsur kepercayaan masyarakat setempat yang menanamkan kepercayaan terhadap kekuasaan arwah nenek moyang dan penguasa dari lingkungan hidup masyarakat, atas dasar kepercayaan tersebut masyarakat mempercayai bahwa setiap benda memiliki penunggu atau penghuninya, demikian juga dengan kayu, kayu merupakan bahan utama dalam pembutan jalur, sehingga dengan didasari oleh kepercayaan tersebut kayu disini dianggap mempunyai tuah yakni kayu yang mempunyai mambang (sejenis makhluk halus) yang mampu dikendalikan pawang atau dukun, sehingga pawang mampu berkomunikasi dan memelihara hubungan yang baik dengan penunggu jalur agar bisa membawa kebaikan bagi masyarakat desa dan saat jalur berpacu bisa meraih kemenangan dengan bantuan dari mambang jalur.

Adapun kegiatan Pacu Jalur diarena perlombaan (tepian sungai kuantan) merupakan puncak dari seluruh prosesi sebuah jalur. diarea inilah satu jalur diuji kemampuannya begitu juga dengan dukun yang memegang jalur sejak awal. namun analisis awal yang mengkaitkan antara seni tari tukang tari Pacu Jalur saat perlombaan berlangsung melihat berdasarkan kepercayaan masyarakatnya yang mana tukang tari jalur yang berada dijalur yang sedang berpacu merupakan gambaran dari mambang jalur tersebut, adapun unsur yang memperkuat kepercayaan tersebut disebabkan dengan mampunya para tukang tari jalur menari diatas jalur yang sedang berpacu dengan seimbang dan baik serta memukau para penonton dengan bentuk gerak yang disajikan bersamaaan dengan percikan air sungai kuantan oleh para pendayung jalur.

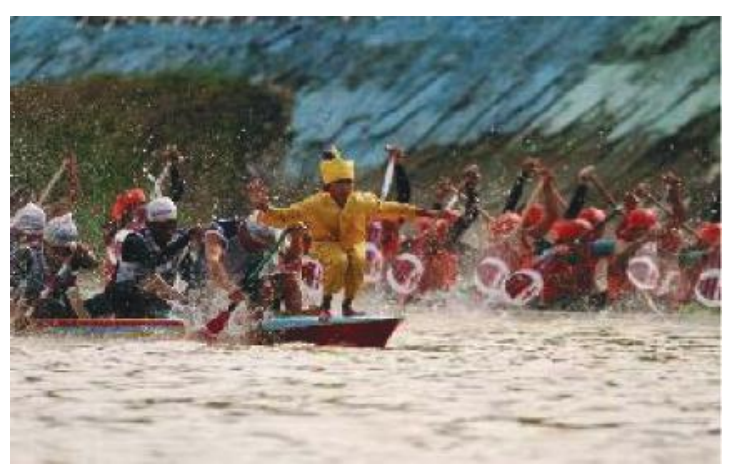

Tukang Tari Jalur

Dokumentasi Pacu Jalur Tahun 2016 (Lokasi Tepian Narosa Teluk Kuantan)

Hal pendukung lainya yang menambah kepercayaan dari bentuk magis, apabila mambang tidak sesuai dengan yang menaiki jalur maka mereka akan sakit setelah menaiki jalur tersebut, ini menandakan bahwa mambang jalur tidak menerima. adapun kepercayaan lain 
dari masyarakat bahwa sesungguhnya saat jalur telah sampai di desa maka mambang jalur sudah menentukan siapa saja yang boleh menakinya, seperti halnya Tukang tari jalur. Tukang tari jalur sendiri telah dipilih mambang jalur, sebab resiko tukang tari jalur juga sangat tinggi saat proses pacu berlangsung yang mana tukang tari jalur ini harus ditarikan oleh anak-anak (10-12 tahun) yang nantinya akan menerima resiko jatuh kedalam sungai kuantan saat sedang berpacu dengan kedalaman sungai kuantan 6-8 meter.

Sementara itu seperti yang telah dijelsakan bahwa bentuk dan motif gerak Tukang tari jalur sendiri tidak dapat dijabarkan karena pada bentuknaya sendiri tari dari tukang tari jalur ini dilakukan secara spontan sehingga tidak ada bentuk gerak yang sama karena masyarakat percaya bahwa saat menari tersebut tukang tari sudah dikuasai oleh mambang jalur. Gerak tari yang dilakukan oleh Tukang Tari jalur sendiri berbeda-beda dan tidak dapat dilihat bentuk serta motifnya. Berdasarakan wawancara secara pribadi terhadap para Tukang Tari setelah selesai berpacu ia mengatakan tidak mengingat tentang apa yang telah dilakukan di atas jalur tersebut, bentuk gerak seperti apa Tukang Tari tak bisa menyontohkan kembali apa yang sudah ia lakukan (Wawancara bersama Rizul Putra : Tukang Tari Jalur Lintah Jalang pada Tanggal 22 Agustus 2015).

Melihat dari pembahasan ini Tradisi $\mathrm{Pacu}$ Jalur merupakan kesatuan kompleks yang berakar dari kepercayaan yag ditanamkan oleh masyarakat sekitar, yang mana berdasarkan teori magis sendiri Menurut Frazer, magis itu dibangun berdasarkan asumsi bahwa ketika satu ritual dilakukan secara tepat, maka akibat yang ditimbulkan juga akan terwujud seperti yang diharapkan. Sehingga pembentukan persepsi dan gusesti yang telah ditanamkan menjadi bentuk pola pikir yang sudah ada kemudian di teruskan melalui asas tradisi dan kepercayaan masyarakat tersebut. Kriteria dari Frazer, yang juga menandaskan bahwa magi sebagai kontrol manusia terhadap alam, dengan kekuatan mantra yang penuh kuasa dan agama sebagai kepercayaan manusia pada kekuatan roh lewat permohonan dan doa.

\section{KESIMPULAN}

Tradisi Pacu Jalur pada masyarakat Kuantan Singingi merupakan bentuk peninggalan kebudayaan yang mengaitkan antara nilai-nilai filosfis kehidupan masyarakat yang mengadung unsur kesenian, olahraga, mitos, dan magis. unsur magis pada tradisi Pacu Jalur sendiri merupakan kepercayaan yang disebabkan oleh tradisi leluhur yang terus diturunkan melalui lisan dan pelaksanaan yang dilakukan oleh masyarakat setempat. adapun pada prosesi pelaksanaan yang selalu dikaitkan dengan unsur magis ini tak lepas dari pemahaman dan prosesi yang telah dilaksanakan dan diikuti oleh seluruh mayarakat. Pada unsur magis seni tari Pacu Jalur merupakan unsur yang pada pelaksanaan dan penerapannya mengandung beberapa kemungkinan yang tidak bisa diterima oleh alam sadar masyarakat sehingga proses tersebut dikaitkan dengan magis agar mendapatkan penjelasan berdasarkan dari unsur mitos ataupun magis yang sudah berkembang sebelumnya. Yang mana pada teori magis menurut Frazer disini menjelaskan bagaimana keterkaitan antara unsur magis dengan kehidupan dan perspektif yang sudah ditatamkan di masyarakat yang juga menghubungkan dirinya dengan kekuatan yang melapaui alam dan manusia.

\section{DAFTAR PUSTAKA}

Asori (et. all). 2015. Olahraga dan Magis (Kajian Terhadap Tradisi Pacu Jalur di Kabupaten Kuantan Singingi) . Pekan Baru: Asa Riau .

Buku Panduan Pemerintah Provinsi Riau Dinas Kebudayaan dan Pariwisata Tahun 2015.

Dapertemen Pendidikan dan Kebudayaan Proyek Iinvestasi dan Dokumentasi Kebudayaan Daerah. 1993. Geografi Budaya Daerah Riau. Jakarta: Dep. P dan K

Dhavamony, Mariasusai. 2010. Fenomenolog Agama. Yogyakarta: Kanisius.

Gafur, Abdul. 2007. Al-Quran dan Budaya Magi (Studi Antropologis Komunitas Kraton Yogyakarta dalam Memaknai Al-Quran dengan Budaya Magi). Tesis 2, Program Pascasarjana UIN Sunan Kalijaga. 
Hamidi,UU. 1986. Dukun Melayu Rantau Kuantan Riau. Pekanbaru : Dapartemen Pendidikan dan Kebudayaan.

Hawkins, Alma. 1990. Mencipta Lewat Tari. Yogyakarta: Institut Seni Indonesia.

Jazuli, Muhammad. 2014. Sosiologi Seni. Yogyakarta. Graha Ilmu.
Suwardi. 2011.Sejarah Pembentukan Kabupaten Kuantan Singingi ( Kebudayaan dan objek parawisata ). Pekan Baru: Asa Riau.

Umar (et. all). 1978. Adat Istiadat Daerah Riau. Proyek Penelitian dan Pencatatan Kebudayaan Daerah Dapertemen Pendidikan dan kebudayaan. 